Original article

\title{
Temperature of rice spikelets: thermal damage and the concept of a thermal burden
}

\author{
John E. Sheehy ${ }^{a *}$, Peter L. Mitchell ${ }^{\mathrm{b}}$, David J. Beerling ${ }^{\mathrm{b}}$, Tadashi Tsukaguchic, \\ F. Ian Woodward ${ }^{\mathrm{b}}$ \\ a International Rice Research Institute, P.O. Box 933, 1099 Manila, Philippines \\ ${ }^{b}$ Department of Animal and Plant Sciences, University of Sheffield, Sheffield S10 2UQ, UK \\ ${ }^{c}$ Faculty of Agriculture, Kyoto University, Sakyo, Kyoto 606, Japan
}

(Received 10 January 1998; accepted 9 July 1998)

\begin{abstract}
The temperature of an inanimate object can be expressed as the sum of air temperature and a temperature term called the 'thermal burden'. The thermal burden depends on the size and shape of an object and its environment. The temperature of rice spikelets can be thought of in the same way except that they can offset some of the thermal burden by transpirational cooling. Using simple theory and measurements we derive values of the thermal burden, the boundary layer resistance and resistance to water loss of spikelets by comparing adjacent panicles, one of which had been severed by a stem borer and was unable to transpire. Close to midday a spikelet at the top of the canopy had a thermal burden of approximately $5{ }^{\circ} \mathrm{C}$, the maximum achievable thermal burden was calculated to be approximately $20^{\circ} \mathrm{C}$. Spikelet resistance to water vapour loss varied from 173 to $851 \mathrm{~s} \mathrm{~m}^{-1}$, boundary layer resistance was approximately $17 \mathrm{~s} \mathrm{~m}^{-1}$. The fertility of rice spikekets declines when the daily maximum air temperatures is above $33{ }^{\circ} \mathrm{C}$, to zero at $40{ }^{\circ} \mathrm{C}$. Because of the interaction between the thermal burden and spikelet transpiration, tissue temperature should be used to describe thermal damage rather than air temperature. The objective of the work described was to develop a simple model of thermal exchanges that could be used to investigate thermal damage to rice spikelets. (C) Inra/Elsevier, Paris.)
\end{abstract}

rice spikelet / transpiration / temperature / boundary layer resistance / thermal burden

Résumé - Température des épillets de riz : dégâts thermiques et le concept de charge thermique. La température d'un objet inerte peut être exprimée comme la somme de la température de l'air et d'un terme appelé «charge thermique ». La charge thermique dépend de la taille et de la forme de l'objet, ainsi que de son environnement. La température des épillets de riz peut être évaluée en considérant comme dépendante de ces deux termes excepté que dans le cas des épillets une compensation partielle de la charge thermique est possible par le refroidissement lié a la transpira-

Communicated by Gérard Guyot (Avignon, France)

* Correspondence and reprints

E-mail: j.sheehy@cgiar.org 
tion. L'usage d'une approche théorique simplifiée et de mesures nous a permis d'évaluer la charge thermique, la résistance de la couche limite et la résistance des épillets aux pertes d'eau par une comparaison avec les panicules adjacentes, dont l'une d'elle, sévèrement attaquée par un insecte foreur de tige, était incapable de transpirer. Vers midi, un épillet situé au sommet de la canopée a une charge thermique d'environ $5^{\circ} \mathrm{C}$. La valeur maximale pouvant être atteinte par la charge thermique a été calculée à environ $20^{\circ} \mathrm{C}$. La résistance des épillets à l'évaporation a varié de $173 \mathrm{~s} \mathrm{~m}^{-1}$ à $851 \mathrm{~s} \mathrm{~m}^{-1}$. La résistance de la couche limite était d'environ $17 \mathrm{~s} \mathrm{~m}^{-1}$. La fertilité des épillets de riz décline lorsque la température maximale journalière de l'air dépasse $33^{\circ} \mathrm{C}$, jusqu'à être nulle à $40^{\circ} \mathrm{C}$. En raison de l'interaction entre la charge thermique et la transpiration des épillets, la température des tissus devrait être utilisée pour décrire les dommages thermiques plutôt que la température de l'air. L'objectif des travaux décrits dans cet article est d'élaborer un modèle d'échanges thermiques simples qui pourrait être utilisé pour étudier les dégâts causés par les fortes températures aux épillets d'une panicule de riz. (@ Inra/Elsevier, Paris.)

\section{épillets de riz / transpiration / température / résistance de la couche limite / charge thermique}

\section{INTRODUCTION}

In a world of doubled carbon dioxide concentration, a general warming of $1.5-4.5^{\circ} \mathrm{C}$ is expected in the latter half of the next century $[18,7]$. In the absence of increased transpiration, plant temperatures will be higher and could cross thresholds for damage more often. Air temperature is often a poor guide to the temperature of an object and this is particularly true for plant organs. Inanimate objects do not transpire and their temperature can be expressed as the sum of air temperature and a temperature term called, for convenience, the 'thermal burden'. The magnitude of the thermal burden is largely a function of the size and shape of an object and its environment; in particular, wind speed and radiation. Thus, identical objects in air of the same temperature may exhibit different surface temperatures depending on the thermal burdens associated with the two environments. The temperature of plant organs can be thought of in the same way, except that they can offset some of the thermal burden by transpirational cooling, so that for a given air temperature their temperature is less predictable than that of a dry object.

For living plant organs to survive, they must avoid experiencing temperatures above the threshold temperatures at which irreversible thermal damage commences. Threshold temperatures for thermal damage to plant organs lie in the range $32-60{ }^{\circ} \mathrm{C}[11,14,28,38]$. Air temperature, radiation, wind speed and transpiration all influence organ temperature as does location within a crop, canopy architecture and the orientation of organs. Plant organs in sunflecks experience more exacting circumstances for temperature control [30] than organs at the very top of the canopy owing to their larger boundary layer resistance and a limited ability to exchange longwave radiation with the sky. Rackham [27] recorded heat damage on herbaceous plants in a sunfleck on the ground beneath a tree canopy. Organs inside an enclosure experience a different thermal environment from those growing in the field. The air temperature is often higher and the longwave exchange with the sky is replaced by exchange with the glass or plastic roof and sides that are often at a much higher effective temperature than the sky.

Thermal damage to rice spikelets results from particular combinations of temperature, radiation, wind speed and inadequate transpirational cooling. Using enclosures of various sorts it has been observed that the fertility of rice spikelets declines from $100 \%$ when the daily maximum air temperatures is $33{ }^{\circ} \mathrm{C}$ to $0 \%$ when that temperature is $40{ }^{\circ} \mathrm{C}[11,28]$. It is interesting to ask why at a temperature of approximately $37.5{ }^{\circ} \mathrm{C}$ half of the spikelets are found to be sterile and half are not. There could be a number of possible answers: a) flowering and pollination occur at different times during the day and $50 \%$ achieve it before temperatures rise to a critical level; b) some spikelets are more at risk from thermal damage because of their location in the canopy; c) some spikelets can tran- 
spire more rapidly than others and maintain a temperature below the critical value for damage. Transpirational cooling often prevents high temperature damage and spikelet temperatures can fall below air temperature [22].

For objects of simple shape, formulae modified from engineering [13] can be used together with values of wind speed to estimate boundary layer resistance. Alternatively, a physical model can be constructed from which heat loss can be measured [3]. Neither of these approaches is easily applied to the rice panicle. In this paper, we derive as a 'rule of thumb' an equation that defines the thermal burden of a spikelet and test its usefulness, in particular for calculating the boundary layer resistance which would be difficult to measure. We compare theory and measurements and derive values of the thermal burden, the boundary layer resistance and resistance to water loss of spikelets by measuring the temperature of adjacent panicles, one transpiring and one not. Non-transpiring panicles were available as the result of the activities of the stem borer (Scirpophaga incertulas). The larva of this moth bores through the sheath of the flag leaf and completely severs the culm. Because the severed point is deep within the leaf sheath, the panicle remains in place, but without vascular connections and is therefore unable to replace water lost. These panicles dry out and ultimately lose colour and are known as whiteheads. They provide panicles that are not transpiring, but are otherwise similar in boundary layer characteristics to the intact panicles. A major objective was to determine if the conceptual approach of the work described in this paper was valid and justified a wider and more detailed study of the issues surrounding thermal damage to spikelets.

\section{THEORY AND BACKGROUND}

\subsection{General considerations}

The avoidance of thermal damage is one of our principal interests, and so we concentrate on the extreme case of a clear sky and a limited tempera- ture range around the threshold temperatures for thermal damage. These are the conditions commonly experienced during the dry season in the tropics. Our principal objective in this paper is to analyse thermal conditions of spikelets in a simple manner. We adopt the view of Goudriaan [8] that simple models which 'highlight the features' have great value and we approximate the physical principles that have been analysed elsewhere $[6,10$, $21,23]$. We assume that the two surfaces of a spikelet, lemma and palea, have identical characteristics. We begin by deriving an expression for the thermal burden of a non-transpiring spikelet and we use the concept of offsetting part of the thermal burden by transpiration to describe the temperature of a transpiring spikelet.

The energy balance of a wet object can be written

$\Theta \frac{d T}{d t}=A\left[\beta R_{g}-R_{n e l l w}-F_{H}-\lambda F_{w}-F_{w} c_{w}(T-T)\right]$

where $\Theta$ is the thermal capacity of the object (mass $\times$ specific heat capacity, $\mathrm{J} \mathrm{K}^{-1}$ ), $\mathrm{T}$ is the temperature of the object $\left({ }^{\circ} \mathrm{C}\right), \mathrm{t}$ is time $(\mathrm{s}), \mathrm{A}$ is the total surface area, $\beta$ is the fraction of solar (shortwave) radiation absorbed, $\mathrm{R}_{\mathrm{g}}$ is the incident global radiation $\left(\mathrm{Wm}^{-2}\right), \mathrm{R}_{\text {netlw }}$ is the net longwave radiation emitted or absorbed $\left(\mathrm{W} \mathrm{m}^{-2}\right)$ and $\mathrm{F}_{\mathrm{H}}$ is the sensible flux density $\left(\mathrm{W} \mathrm{m}^{-2}\right), \mathrm{F}_{\mathrm{W}}$ is the water vapour flux density $\left(\mathrm{kg} \mathrm{m}^{-2} \mathrm{~s}^{-1}\right)$ which when multiplied by the latent heat of vaporization gives the latent heat flux density $\left(\mathrm{W} \mathrm{m}^{-2}\right), \mathrm{c}_{\mathrm{w}}$ is the specific heat capacity of water $\left(\mathrm{J} \mathrm{kg}^{-1} \mathrm{~K}^{-1}\right), \mathrm{T}_{\mathrm{i}}$ is the temperature of the incoming water $\left({ }^{\circ} \mathrm{C}\right)$ and $\lambda$ is the latent heat of vaporization of water $\left(\mathrm{J} \mathrm{kg}^{-1}\right)$.

The energy balance of a dry object is obtained by setting $\mathrm{F}_{\mathrm{W}}$ to zero and applying standard micrometeorological theory. We assume that $80 \%$ of visible $(400-700 \mathrm{~nm})$ and $20 \%$ of short-wave infra-red radiation $(700-2400 \mathrm{~nm})$ is absorbed and the visible and infra-red components each comprise $50 \%$ of the global radiation [20]. This is equivalent in energy terms to assuming that the spikelets absorb all incident visible radiation $I_{p}$. Therefore the energy balance of an object such as a 
spikelet on a panicle recently severed by a stemborer (whitehead) can be written

$$
I_{p}=R_{l w}+R^{\prime}{ }_{l w}+\rho c_{p} \frac{T_{S}-T_{A}}{r_{b h}}
$$

where $I_{p}$ represents incident visible shortwave or photosynthetically active radiation (PAR, $400-700 \mathrm{~nm}, \mathrm{~W} \mathrm{~m} \mathrm{~m}^{-2}$ ) and $\beta \mathrm{R}_{\mathrm{g}}=\mathrm{I}_{\mathrm{p}}$, the lemma and palea are assumed to be leaf-like; $\mathrm{R}_{\mathrm{lw}}$ and $\mathrm{R}_{\mathrm{lw}}^{\prime}$ are the net longwave radiation exchanged with the environment upwards and downwards $\left(\mathrm{W} \mathrm{m}^{-2}\right) ; \rho$ is the density $\left(\mathrm{kg} \mathrm{m}^{-3}\right)$ and $\mathrm{c}_{\mathrm{p}}$ is the specific heat capacity of air $\left(\mathrm{J} \mathrm{kg}^{-1} \mathrm{~K}^{-1}\right) ; \mathrm{T}_{\mathrm{S}}^{\mathrm{p}}$ is spikelet temperature $\left({ }^{\circ} \mathrm{C}\right)$ and $\mathrm{T}_{\mathrm{A}}$ is air temperature and $\mathrm{r}_{\mathrm{bh}}$ is the boundary layer resistance to sensible heat for upper and lower surfaces together, i.e. $r_{b h}=r_{a} / 2$ where $r_{a}$ is the boundary layer resistance for one side only.

For spikelets at the top of the canopy the upper surfaces will be assumed to exchange longwave radiation with the sky and the lower surfaces to exchange longwave radiation with shaded leaves assumed to be at air temperature. For clear skies, the exchange of longwave radiation with the sky, $\mathrm{R}_{\mathrm{lw}}$, can be calculated by combining the longwave radiation emitted by the sky $\left(1.2 \sigma \mathrm{T}_{\mathrm{KA}}-171\right)$ as summarized by Swinbank [33] as a function of air temperature with the longwave radiation emitted by the spikelet described by the Stefan-Boltzmann law $\left(\varepsilon \sigma \mathrm{T}_{\mathrm{KS}}{ }^{4}\right)$ where $\sigma$ is the Stefan-Boltzmann constant and $\varepsilon$ is the emissivity, assumed to be 1 for spikelets and the subscript $\mathrm{K}$ indicates temperature in Kelvin. For a limited range of temperature both sky and spikelet longwave radiation emission can be approximated by straight lines [19] and we can write $\mathrm{R}_{\mathrm{lw}}$ as the difference between those two straight line approximations

$$
R_{1 w}=\left(m_{\text {spik }} T_{S}+C_{\text {spik }}\right)-\left(m_{\text {sky }} T_{A}+C_{\text {sky }}\right)
$$

where the units are $\mathrm{Wm}^{-2}$ for the intercepts of the straight line approximations (c) and for the slopes (m) are $\mathrm{Wm}^{-2}{ }^{\circ} \mathrm{C}^{-1}$.

Similarly for the fluxes on the lower surface when the shaded leaves are at air temperature

$$
\mathrm{R}_{\text {iw }}^{\prime}=\mathrm{m}_{\text {spik }} \mathrm{T}_{\mathrm{S}}-\mathrm{m}_{\text {spik }} \mathrm{T}_{\mathrm{A}}
$$

These relationships are shown in figure $I$. Substituting in equation (2) and rearranging

$$
\mathrm{T}_{\mathrm{S}}=\mathrm{T}_{\mathrm{A}}\left[\frac{\mathrm{m}_{\mathrm{sky}}+\mathrm{m}_{\text {spik }}+\frac{\rho \mathrm{c}_{\mathrm{p}}}{\mathrm{r}_{\mathrm{bh}}}}{2 \mathrm{~m}_{\mathrm{spik}}+\frac{\rho \mathrm{c}_{\mathrm{p}}}{\mathrm{r}_{\mathrm{bh}}}}\right]+\left[\frac{\mathrm{I}_{\mathrm{p}}+\mathrm{c}_{\mathrm{sky}}-\mathrm{c}_{\mathrm{spik}}}{2 \mathrm{~m}_{\mathrm{spik}}+\frac{\rho \mathrm{c}_{\mathrm{p}}}{\mathrm{r}_{\mathrm{hh}}}}\right]
$$

This can be written as

$$
\mathrm{T}_{\mathrm{S}}=\alpha \mathrm{T}_{\mathrm{A}}+\mathrm{T}_{\mathrm{B}}
$$

where $T_{B}$ is the thermal burden.

For a limited temperature range relevant to higher air temperatures and spikelets close to the top of the canopy $\alpha$ is approximately unity and we can write

$$
\mathrm{T}_{\mathrm{S}}=\mathrm{T}_{\mathrm{A}}+\mathrm{T}_{\mathrm{B}}
$$

The thermal burden is equivalent to radiation increment used by animal physiologists [21] and can be written

$$
\mathrm{T}_{\mathrm{B}}=\frac{\mathrm{I}_{\mathrm{p}}+\mathrm{c}_{\mathrm{sky}}-\mathrm{c}_{\mathrm{spik}}}{2 \mathrm{~m}_{\mathrm{spik}}+\frac{\rho \mathrm{c}_{\mathrm{p}}}{\mathrm{r}_{\mathrm{bl}}}}
$$

In an undamaged spikelet transpiration can offset some part, $f$, of the thermal burden so that its temperature, $T_{S}^{\prime}$, is given by

$$
T^{\prime}{ }_{S}=T_{A}+T_{B}(1-f)
$$

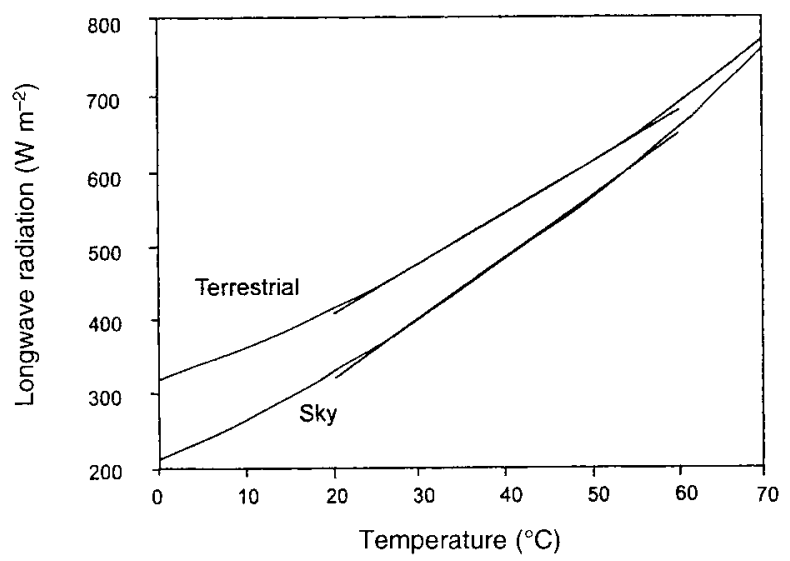

Figure 1. Longwave radiation emitted by terrestrial surfaces or the sky as a function of the surface or air temperature. The curve is the fourth power relationship and the straight line is an approximation for $20-60{ }^{\circ} \mathrm{C}$. The slopes of the lines are $8.37\left(\mathrm{~m}_{\text {sky }}\right)$ and $6.98\left(\mathrm{~m}_{\text {spik }}\right)$ in $\mathrm{W} \mathrm{m}^{-2}{ }^{\circ} \mathrm{C}^{-1}$, and the intercepts are $154\left(\mathrm{c}_{\mathrm{sky}}\right)$ and $271\left(\mathrm{C}_{\mathrm{spik}}^{\mathrm{spik}}\right)$ in $\mathrm{W} \mathrm{m}^{-2}$. 
The principle of energy conservation can be applied to the transpiring and non-transpiring spikelet and the difference in sensible heat and radiant heat must be equal to the difference in transpiration. These terms are balanced by the energy dissipated in transpiration, thus after some algebra it can be shown that the latent heat dissipated in transpiration by a spikelet, $\lambda F_{W}\left(\mathrm{~W} \mathrm{~m}^{-2}\right)$, is given by

$$
\lambda F_{W}=f T_{B}\left(2 m_{\text {ppik }}+\frac{\rho c_{p}}{r_{b h}}\right)
$$

Given the thermal burden, the value of ' $f$ ' for any desired spikelet temperature can be computed by setting $T^{\prime}{ }_{S}$ to $T_{\text {crit }}$ and rearranging equation (9) as

$$
\mathrm{f}_{\text {cril }}=1-\frac{\mathrm{T}_{\text {crit }}-\mathrm{T}_{\mathrm{A}}}{\mathrm{T}_{\mathrm{B}}}
$$

The critical temperature can be the threshold temperature at which thermal damage starts, or simply $\mathrm{T}_{\mathrm{A}}$ to examine the conditions in which the whole thermal burden is offset by transpiration. If the value of ' $f$ ' is greater than 1 , then the thermal burden is more than offset so that the spikelet is cooler than the air. The value of $f_{\text {crit }}$ will provide maximum resistance, stomatal and cuticular, compatible with desired spikelet temperature, e.g. less than $33{ }^{\circ} \mathrm{C}$. From equation (10) we can write [9]

$$
\frac{\rho c_{\mathrm{p}}\left(e_{\mathrm{s}}-e_{\mathrm{i}}\right)}{\gamma \frac{\mathrm{r}_{\mathrm{sp}}+\mathrm{r}_{\mathrm{bw}}}{2}}=\mathrm{fT}_{\mathrm{B}}\left(2 \mathrm{~m}_{\mathrm{spik}}+\frac{\rho \mathrm{c}_{\mathrm{p}}}{\mathrm{r}_{\mathrm{bh}}}\right)
$$

where $e_{\mathrm{s}}$ and $\mathrm{e}_{\mathrm{a}}$ are the vapour pressures inside the spikelet and air, respectively, $\gamma$ is the psychrometric constant, $r_{b w}$ is the boundary layer resistance for water vapour and $r_{S p}$ is spikelet resistance. Assuming that the upper and lower resistances are the same then the total resistance for the spikelet is $\left(r_{S p}+r_{b w}\right) / 2$. It is convenient to have $r_{b w}$ in terms of $r_{b h}$. The factor converting boundary layer conductance for heat to that for water is 1.08 [13]. Converting for use with resistances $r_{b w}=(1 / 1.08) r_{a}$ $=0.926 \mathrm{r}_{\mathrm{a}}=1.85 \mathrm{r}_{\mathrm{bh}}$, as $\mathrm{r}_{\mathrm{bh}}=\mathrm{r}_{\mathrm{a}} / 2$. The spikelet resistance (one side) can be written in terms of the stomatal resistance, $r_{s}$, and the cuticular resistance, $r_{c}$

$$
r_{S p}=\frac{r_{s} r_{c}}{r_{s}+r_{c}}
$$

Substituting in equation (12) for $T_{B}$ (equation (8)) and for $r_{b w}$ we obtain the value for spikelet resistance (one side) at any value of $f$

$$
r_{S p}=\frac{2 \rho c_{p}\left(e_{s}-e_{i a}\right)}{\gamma f\left(I_{p}+c_{s k y}-c_{s p i k}\right)}-1.85 r_{h h}
$$

Another useful equation describing the dependence of the transpiration rate on radiation and the fraction of the thermal burden offset by transpiration can also be derived by rearranging equation (10)

$$
F_{W}=\frac{f\left[I_{p}+c_{\text {sky }}-c_{\text {spik }}\right]}{\lambda}
$$

the simplest case is when spikelet and air temperature are equal $(f=1)$ and the rate of transpiration would be approximately $0.17 \mathrm{~g} \mathrm{~m}^{-2} \mathrm{~s}^{-1}$ when $\mathrm{I}_{\mathrm{p}}=$ $500 \mathrm{~W} \mathrm{~m}^{-2}$.

\subsection{Spikelets in sunflecks}

In general, considering the canopy as a homogeneous whole, $I_{p}$ declines exponentially with depth when depth in the canopy is measured as leaf area index [13]. Similarly, mean wind speed decreases logarithmically with depth so that $r_{b h}$ increases. Thus, leaves deep in the canopy can have large $r_{b h}$ but do not experience high temperature, unless exposed in a sunfleck to large amounts of direct beam PAR, $I_{p h}$. The solar disc subtends about $1 / 2^{\circ}$ of an arc at the earth's surface or $5.98 \times 10^{-5}$ steradian. This is less than $0.001 \%$ of the hemisphere of the sky. A canopy hole of this size causes penumbral effects [30] but even a hole of $5^{\circ}$ diameter occupies only $0.1 \%$ of the hemisphere and a circular hole has to be $36^{\circ}$ in diameter to occupy $5 \%$ of the sky. Thus, the longwave loss to the sky is negligible. A spikelet in the canopy is exchanging longwave radiation with leaves above and 
below it. If the surrounding leaves are assumed to be at air temperature the thermal burden can be calculated as before omitting the term $\left(\mathrm{c}_{\text {sky }}-\mathrm{c}_{\text {spik }}\right)$ as there is no effective longwave radiation exchange with the sky in the sunfleck and replacing $I_{p}$ by $I_{p b}$ which gives

$$
\mathrm{T}_{\mathrm{BSF}}=\frac{\mathrm{I}_{\mathrm{pb}}}{2 \mathrm{~m}_{\mathrm{spik}}} \frac{\overline{\rho \mathrm{c}_{\mathrm{p}}}}{\mathrm{r}_{\mathrm{bh}}}
$$

The difference between the thermal burdens in the sunfleck and non-sunfleck cases is the result of the difference between $\mathrm{I}_{\mathrm{pb}}$ and $\left(\mathrm{I}_{\mathrm{p}}+\mathrm{c}_{\mathrm{sky}}-\mathrm{c}_{\mathrm{spik}}\right)$. Thus, for peak values of radiation $\left(I_{p b} \approx 0.7 I_{p}\right.$, $\mathrm{c}_{\mathrm{sky}}-\mathrm{c}_{\mathrm{spik}}=-117 \mathrm{~W} \mathrm{~m}^{-2}$ ) the difference between the two thermal burdens arises more from differences in boundary layer resistance caused by differences in wind speed between the top of the canopy and its interior. The boundary layer resistance for heat depends on the size of the plant part and the wind speed [13]. Most values fall in the range $10-100 \mathrm{~s} \mathrm{~m}^{-1}$. Values lower than this can occur with small parts in high wind speeds. Boundary layer resistances of $200 \mathrm{~s} \mathrm{~m}^{-1}$ or more can occur only with very large leaves (e.g. banana) with characteristic dimension, $\mathrm{d}$, of $0.5 \mathrm{~m}$ and low wind speeds $\left(0.1 \mathrm{~m} \mathrm{~s}^{-1}\right)$, or with normal leaves $(\mathrm{d}=0.01-0.1 \mathrm{~m})$ and exceptionally still air $\left(<0.01 \mathrm{~m} \mathrm{~s}^{-1}\right)$. Deep in a leaf canopy there is little air movement and $r_{b h}$ can be high: Woodward and Sheehy [35] recorded $160 \mathrm{~s} \mathrm{~m}^{-1}$ at $0.1 \mathrm{~m}$ above ground in a ryegrass canopy $0.3 \mathrm{~m}$ tall; at the top of the canopy the resistance was $23 \mathrm{~s} \mathrm{~m}^{-1}$.

\subsection{Temperature}

The maximum air temperatures usually experienced in rice growing areas are often no greater than $35{ }^{\circ} \mathrm{C}$; nevertheless, many of those areas appear to have experienced exceptional temperatures in excess of $40{ }^{\circ} \mathrm{C}$ [4]. The highest air temperatures recorded are $49,53,54,57$ and $58{ }^{\circ} \mathrm{C}$ for the land masses of South America, Australia, Eurasia, North America and Africa, respectively $[1,34]$. Most of the highest temperatures are recorded in or around the Sahara; conversely about $17 \%$ of the earth's land surface never experiences temperatures above $40^{\circ} \mathrm{C}[34]$.

\subsection{Radiation}

Solar radiation recorded at the earth's surface can be as high as $1430 \mathrm{~W} \mathrm{~m}^{-2}$ [29], but a peak value of about $1000 \mathrm{~W} \mathrm{~m}^{-2}$ is generally observed. This corresponds to an $\mathrm{I}_{\mathrm{p}}$ value of $500 \mathrm{~W} \mathrm{~m}^{-2}$.

\subsection{Resistances}

Stomatal resistance to water movement for a leaf of an individual species can be changed by $1-2$ orders of magnitude as the aperture varies in size but there is a considerable range of values across different types of plant [13]; a value of $54 \mathrm{~s} \mathrm{~m}^{-1}$ was recorded for rice leaves [26]. The lemma and palea have stomata [12]; however, OToole et al. [25] reported that diffusive resistances for spikelets remained at $150 \mathrm{~s} \mathrm{~m}^{-1}$ across a wide range of panicle water contents suggesting that there was no stomatal mechanism for controlling water loss.

\subsection{The size of thermal burdens}

The thermal burden as a function of boundary layer resistance to heat is shown in figure 2 for a spikelet at the top of the canopy. For most conditions $T_{B}$ is in the range $2-20{ }^{\circ} \mathrm{C}$, depending on $r_{b h}$ and incident radiation. The observed differences between temperatures of air and non-transpiring leaves (thermal burdens) for leaves of 17 species in the tropics and temperate regions given by Stoutjesdijk and Barkman [31] range from 7.6 to $21.4{ }^{\circ} \mathrm{C}$. Using the values described in the sections above, $\mathrm{Ip}=500 \mathrm{Wm}^{-2}, \mathrm{r}_{\mathrm{bh}}=23 \mathrm{~s} \mathrm{~m}^{-1}$, in equation (7) the thermal burden of a spikelet is predicted to be approximately $6.6^{\circ} \mathrm{C}$. If we assume commonly observed values at IRRI for air temperature, $32{ }^{\circ} \mathrm{C}$, vapour pressure deficit, $1.8 \mathrm{kPa}[4,24]$, and the 


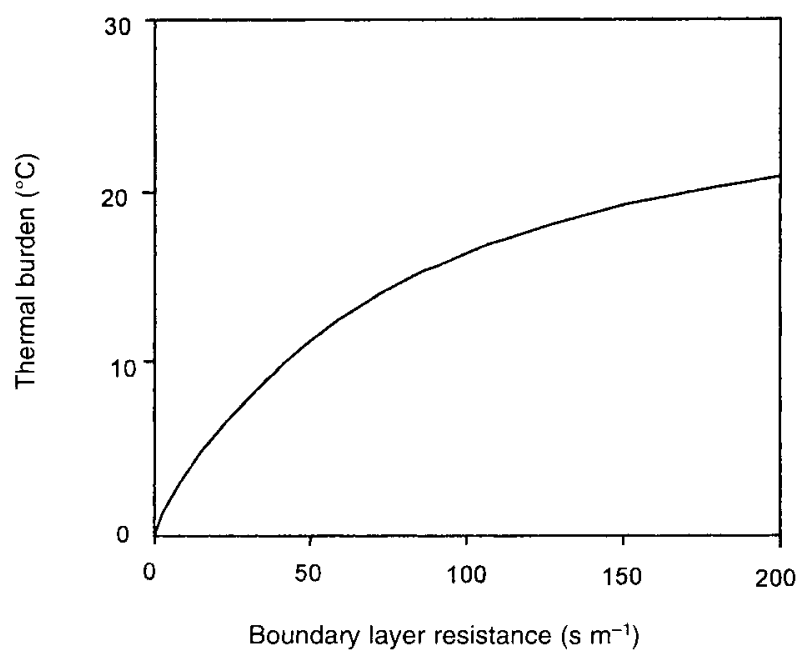

Figure 2. The thermal burden as a function of boundary layer resistance for a spikelet at the top of the canopy receiving $500 \mathrm{~W} \mathrm{~m}^{-2}$ incident PAR.

spikelet resistance reported by OToole et al. [24] of $150 \mathrm{~s} \mathrm{~m}^{-1}$ and these are substituted in equation (14) then the estimated value of $\mathrm{f}$ is 0.88 . Spikelet temperature is predicted from equation (9) to be $0.8{ }^{\circ} \mathrm{C}$ above air temperature.

\section{MATERIALS AND METHODS}

Measurements were made in an experimental crop of the cultivar IR72 grown at IRRI (Philippines, lat. 14" $21^{\prime} \mathrm{N}$, long. $121^{\circ} 23^{\prime} \mathrm{E}$ ) during the dry season of 1977. Those measurements were made on the 8 April 1997 , which was approximately mid-flowering, at the time of flowering, between 1045 and 1200 hours. The crop was transplanted on 27 January, it was irrigated and received abundant fertilizer. Photosynthetically active radiation (PAR, 400-700 nm) was recorded with a Sunscan probe ( $\Delta \mathrm{T}$ devices, Barnwell, near Cambridge, UK), relative humidity was read from a hygrothermograph and wind speed measured with a three cup anemometer at the adjacent meteorological station. The diameter and lengths of ten spikelets were measured using vernier calipers. Temperature measurements were made with a thermocouple thermometer, no other suitable device being available. The thermocouple, diameter $0.5 \mathrm{~mm}$, was brought into contact with the spikelet and the temperature recorded when the meter reading was steady. Bell and Rose [2] discussed the errors of measurement resulting from such a technique which they suggested could be as large as $1 \mathrm{~K}$. Nevertheless to estimate the error a comparison would have to be made of measurements of spikelet temperature taken using infra-red thermometry, infra-red thermal imaging and thermocouple thermometry. Adjacent pairs of panicles were identified, one of which had suffered a recent stem borer attack and was identified as a whitehead. Measurements were made consecutively on spikelets of both panicles and air temperature adjacent to the panicles. Assuming that the radiation error for the thermocouple, $T_{\varepsilon}$, was approximately the same for spikelet and air temperature, then it will cancel out when measurements on whiteheads are used to calculate the thermal burden since $\mathrm{T}_{\mathrm{B}}=\left(\mathrm{T}_{\mathrm{S}}+\mathrm{T}_{\varepsilon}\right)-\left(\mathrm{T}_{\mathrm{A}}+\mathrm{T}_{\varepsilon}\right)$, from equation (7).

\section{RESULTS}

Radiation conditions were clear and sunny throughout the measuring period and 32 measurements of PAR averaged $2242 \pm 1.6 \mu \mathrm{mol} \mathrm{m} \mathrm{m}^{-2} \mathrm{~s}^{-1}$ (mean and standard error of readings, the absolute error is approximately $\pm 3 \%$ ) which is equivalent to $487 \pm 0.4 \mathrm{~W} \mathrm{~m}^{-2}$ [17]. Relative humidity was $70 \pm 3 \%$ and wind speed was $1.8 \pm 0.12 \mathrm{~m} \mathrm{~s}^{-1}$. Spikelet diameter was $2.5 \pm 0.1 \mathrm{~mm}$ and length was $8.7 \pm 0.5 \mathrm{~mm}$ (mean and standard error).

The temperature measurements are shown in table I. Applying equation (7) gives estimates of the thermal burden of the spikelets ranging from 4.8 to $5.4{ }^{\circ} \mathrm{C}$. Then the boundary layer resistance computed from equation (8) varies from 16.0 to $18.5 \mathrm{~s} \mathrm{~m}^{-1}$, values slightly lower than reported for upper leaves of a grass canopy [35]. It is interesting to note that the spikelets of one of the panicles has a resistance to water vapour loss of $173 \mathrm{~s} \mathrm{~m}^{-1}$ in fairly good agreement with the observations of OToole et al. [25], but the spikelet resistances of the remaining three were almost 4-6 times greater than the reported value (table I). Ekanayake et al. [5] observed that panicle resistance increased from approximately $150 \mathrm{~s} \mathrm{~m}^{-1}$ in early flowering to $600 \mathrm{~s} \mathrm{~m}^{-1}$ in late flowering. There are approximately 40000 spikelets per square meter [36] and if we assume that they are cylindrical in shape with a mean surface area of $78 \times 10^{-6} \mathrm{~m}^{2}$ the mean rate of 
Table I. Measurements of temperatures (mean \pm s.e.) and calculated values of thermal burden, resistances and transpiration for rice spikelets (9-12 spikelets measured per panicle of IR72). The four pairs of panicles (A-D) consist of one normal live panicle and an adjacent panicle (whitehead) recently severed by a stemborer (Scirpophaga incertulas).

\begin{tabular}{|c|c|c|c|c|}
\hline & \multicolumn{4}{|c|}{ Pairs of panicles } \\
\hline & A & $\mathrm{B}$ & $\mathrm{C}$ & $\mathrm{D}$ \\
\hline $\begin{array}{l}\text { Unshaded air temperature } \\
\left(\mathrm{T}_{\mathrm{A}}+\mathrm{T}_{\varepsilon}\right)\left({ }^{\circ} \mathrm{C}\right)\end{array}$ & $32.5 \pm 0.1$ & $32.2 \pm 0.1$ & $32.9 \pm 0.1$ & $33.1 \pm 0.1$ \\
\hline $\begin{array}{l}\text { Live panicle spikelet temperature } \\
\left(\mathrm{T}^{\prime}{ }_{\mathrm{S}}+\mathrm{T}_{\varepsilon}\right)\left({ }^{\circ} \mathrm{C}\right)\end{array}$ & $33.6 \pm 0.2$ & $36.1 \pm 0.1$ & $36.1 \pm 0.1$ & $36.2 \pm 0.1$ \\
\hline $\begin{array}{l}\text { Whitehead panicle spikelet temperature } \\
\left(\mathrm{T}_{\mathrm{S}}+\mathrm{T}_{\varepsilon}\right)\left({ }^{\circ} \mathrm{C}\right)\end{array}$ & $37.8 \pm 0.4$ & $37.6 \pm 0.1$ & $37.7 \pm 0.1$ & $38.1 \pm 0.2$ \\
\hline Thermal burden $\left({ }^{\circ} \mathrm{C}\right)$ & 5.3 & 5.4 & 4.8 & 5.0 \\
\hline Boundary layer resistance $\left(\mathrm{s} \mathrm{m}^{-1}\right)$ & 18.1 & 18.5 & 16.0 & 16.8 \\
\hline Transpirational offset fraction $\mathrm{f}$ & 0.79 & 0.27 & 0.33 & 0.38 \\
\hline Spikelet resistance $\left(\mathrm{s} \mathrm{m}^{-1}\right)$ & 173 & 851 & 648 & 598 \\
\hline $\begin{array}{l}\text { Rate of spikelet transpiration } \\
\left(\mathrm{mg} \mathrm{m}^{-2} \mathrm{~s}^{-1}\right)\end{array}$ & 121 & 41.3 & 50.5 & 58.1 \\
\hline
\end{tabular}

transpiration from all of the spikelets in the crop is approximately $0.8 \mathrm{~mm} \mathrm{~h}^{-1}$

\section{DISCUSSION}

The thermodynamic complexity of the relationship between the temperature of a spikelet and its environment can be much simplified using the concept of a thermal burden. This formulation avoids the difficulty of knowing the longwave fluxes or the net radiation of the spikelet by using the Swinbank [33] approximation for longwave radiation emitted by the sky and straight lines for portions of fourth order curves. The simplification works because the equation is for the steady state and is applied to limited conditions, i.e. higher temperatures relevant to thermal damage, clear skies, etc. The maximum thermal burden for vegetation is approximately $20^{\circ} \mathrm{C}$ which when added to air temperatures in excess of $20{ }^{\circ} \mathrm{C}$ would, in the absence of transpiration, cause irreversible thermal damage to rice and many plant species. At an air temperature of $40{ }^{\circ} \mathrm{C}$ rice is completely sterile, at approximately $37{ }^{\circ} \mathrm{C}$ it is $50 \%$ sterile. The results in this paper suggest that measuring air temperature is not the best way to assess thermal damage because of the interaction between the thermal burden and spikelet transpiration. The thermal burden increases with absorbed radiation and boundary layer resistance and so is influenced by depth within the canopy. For example, close to midday in the tropics a spikelet at the top of the canopy has a boundary layer resistance of approximately $17 \mathrm{~s} \mathrm{~m}^{-1}$ and a thermal burden of approximately $5{ }^{\circ} \mathrm{C}$. Within the canopy, the boundary layer resistance could rise to $100 \mathrm{~s} \mathrm{~m}^{-1}$ and in a sunfleck the thermal burden would rise to $17^{\circ} \mathrm{C}$ putting the spikelet at greater risk of thermal damage. Whether damage occurs or not depends on the spikelet resistance to water vapour loss and to avoid damage in this example, the resistance would have to be approximately $100 \mathrm{~s} \mathrm{~m}^{-1}$ which is less than the values estimated in this experiment and those of OToole et al. [25]. It is interesting to note that 
between 14 and $24 \%$ of spikelets in IR 72 remain unfilled at IRRI and that the percentage can vary from year to year even though the total number of spikelets remains constant [36]. In contrast Yoshida and Parao [37] observed that the percentage remained approximately constant (15\%) across experimental treatments and years. It is tempting to suggest that differences between years in air temperature, irradiance and wind speed could give rise to thermal burdens which cannot be offset. Air temperatures as great as $38^{\circ} \mathrm{C}$ have been reported for IRRI [4] so that thermal damage may already be occurring and it needs to be investigated in the field as a matter of some urgency.

The thermal burden in an enclosure might be thought to be larger than in the natural environment simply because the spikelet cannot lose longwave radiation as effectively to the sky. However, the transmission of solar radiation is often sufficiently reduced by the supporting structure of the enclosure to offset the longwave disadvantage so that higher spikelet temperatures inside are, in many conditions, primarily the result of higher air temperatures in the greenhouse. Kennedy [15] has shown that greenhouse experiments require careful analysis to separate the effects of several environmental factors altered at the same time; similar conclusions can be reached for other types of enclosure. This supports the suggestion above that tissue temperatures would be a better guide to physiological phenomena such as thermal damage and spikelet sterility. Furthermore, it would enable direct comparisons with field measurements of spikelet temperature. Measurements made in both environments with a short focal length infra-red thermometer or a thermal infra-red camera would be suitable.

Thermal damage is notable when it occurs because it is exceptional. It requires most of the following factors to be unfavourable together: high air temperature, high solar radiation, low wind speed (high boundary layer resistance), low vapour pressure deficit (small driving force for transpiration), panicles orientated for maximum radiation receipt or in a sunfleck (high boundary layer resistance). Nevertheless, as suggested above these circumstances may be more common than usually assumed. As the rice crop flowers over a period of approximately 20 days between the times of 1000 and 1200 hours, it would only take 5 days of high thermal burden conditions to cause a $25 \%$ loss of fertility. Furthermore, thermal damage could become more common in a world with a warmer climate. In addition to higher air temperature, the increased concentration of carbon dioxide can be associated with higher water use efficiency and higher stomatal resistance. Increases in stomatal resistance and in leaf temperature have been observed on plants grown in chambers with elevated carbon dioxide $[16,32,39]$. It is felt that a more detailed field study of spikelet temperature would be useful given that up to $30 \%$ of them do not fill in IR72 when grown at IRRI. As a consequence of the results in this paper, a more detailed study of the issue of thermal damage to spikelets in a range of cultivars will be undertaken using a thermal infra-red camera and infra-red thermometry. The improved accuracy of the measurements will allow an assessment of the contribution of factors influencing the issue of thermal damage such as: canopy architecture, panicle architecture, spikelet colour, spikelet hairiness and spikelet resistance to transpiration. The simple equations presented here enable this topic to be more easily understood and provide a simple methodology for studying the possible effects of thermal damage to developing spikelets.

Acknowledgements: The ideas in this paper grew out of discussions concerning differences between plant responses in enclosures and the natural environment. Awards to J.E.S. through United States Agency for International Development (USAID) and the Natural Environmental Research Council TIGER (Terrestrial Initiative in Global Environmental Research), FIW (TIGER), DJB through the European Community CLIMEX (Climate Change Experiment) programme; and PLM (TIGER).

\section{REFERENCES}

[1] Ahrens C.D., Meteorology Today: An Introduction to Weather, Climate and the Environment, West, St. Paul, Minnesota, USA, 1991. 
[2] Bell C.J., Rose D.A., The measurement of temperature, in: Marshall B., Woodward F.I. (Eds.), Instrumentation for Environmental Physiology, Cambridge University Press, Cambridge, 1985, pp. 79-99.

[3] Brenner A.J., Jarvis, P.G., A heated leaf replica technique for determination of leaf boundary layer conductance in the field, Agric. For. Meteorol. 72 (1995) 261-275.

[4] Centeno H.G.S., Aclan A.P., Balbarez A.D., Pascual Z.P., Penning de Vries F.W.T., Kropff M.J., The rice weather database, in: Matthews R.B., Kropff M.J., Bachelet D., van Laar H.H. (Eds.), Modeling the Impact of Climate Change on Rice Production in Asia, $\mathrm{CAB}$ International, Wallingford in association with the International Rice Research Institute, Manila, Philippines, 1995, pp. 9-26.

[5] Ekanayake I.J., DeDatta S.K., Steponkus P.L., Effect of water deficit stress on diffusive resistance. transpiration and spikelet desiccation of rice (Oryza sativa L.), Ann. Bot. 72 (1993) 73-80.

[6] Gates D.M., Biophysical Ecology, Springer, Berlin, 1980.

[7] Gates W.L., Mitchell J.F.B., Boer G.J., Cubasch U., Meleshko V.P., Climate modelling, climate prediction and model validation, in: Houghton J.T., Callander B.A., Varney S.K. (Eds.), Climate Change 1992: the Supplementary Report to the IPCC Scientific Assessment, Cambridge University Press, Cambridge, 1992, pp. 97-134.

[8] Goudriaan J., Using the expolinear growth equation to analyze resource capture, in: Monteith J.L., Scott R.K., Unsworth M.H. (Eds.), Resource Capture by Crops, Nottingham University Press, Sutton, 1994, pp. 99-110.

[9] Goudriaan J., van Laar H.H., Modelling Potential Crop growth processes. Textbook with Exercises, Kluwer Academic Publishers, Dordrecht, 1994.

[10] Grace J., Plant-Atmosphere Relationships, Chapman and Hall, London, 1983.

[11] Horie T., Nakagawa H., Centeno H.G.S., Kropff M.J., The rice crop simulation model SIMRIW and its testing, in: Matthews R.B., Kropff M.J., Bachelet D., van Laar H.H. (Eds.), Modeling the Impact of Climate Change on Rice Production in Asia, CAB International, Wallingford in association with the International Rice Research Institute, Manila, Philippines, 1995, pp. 51-66.

[12] Hoshikawa K., The Growing Rice Plant, Nobunkyo, Tokyo, Japan, 1989.
[13] Jones H.G., Plants and Microclimate, Cambridge University Press, Cambridge, 1983.

[14] Kappen L., Ecological significance of resistance to high temperature, in: Lange O.L., Nobel P.S., Osmond C.B., Ziegler H. (Eds.), Encyclopaedia of Plant Physiology, New Series, Vol. 12A, Springer-Verlag, Berlin, 1981, pp. 439-474.

[15] Kennedy A.D., Simulated climate change: are passive greenhouses a valid microcosm for testing the biological effects of environmental perturbations?, Global Change Biol. 1 (1995) 29-42.

[16] Kim H.Y., Horie T., Nakagawa H., Wada K., Effects of elevated $\mathrm{CO}_{2}$ concentration and high temperature on growth and yield of rice. II. The effect on yield and its components of Akihikari rice, Jpn J. Crop Sci. 65 (1996) 634-643.

[17] McCree K.J., Photosynthetically active radiation, in: Lange O.L., Nobel P.S., Osmond C.B., Ziegler H. (Eds.), Encyclopaedia of Plant Physiology, New Series, Vol. 12D, Springer-Verlag, Berlin, 1981, pp. $44-55$.

[18] Mitchell J.F.B., Manabe S., Meleshko V., Tokioka T., Equilibrium climate change and its implications for the future, in: Houghton J.T., Jenkins G.J., Ephraums J.J. (Eds.), Climate Change: the IPCC Scientific Assessment, Cambridge University Press, Cambridge, 1990, pp. 131-174.

[19] Monteith J.L., Light distribution and photosynthesis in field crops, Ann. Bot. 29 (1965) 17-37.

[20] Monteith J.L., Principles of Environmental Physics, Edward Arnold, London, 1973.

[21] Monteith J.L., Coupling of plants to the atmosphere, in: Grace J., Ford E.D., Jarvis P.G. (Eds.), Plants and their Atmospheric Environment, Blackwell, Oxford, 1981, pp. 1-29.

[22] Nishiyama I., Temperature inside the flower of rice plant, Jap. J. Crop Sci. 50 (1981) 54-58.

[23] Nobel P.S., Biophysical Plant Physiology and Ecology, W.H. Freeman, SanFrancisco, 1983.

[24] OToole J.C., Tomar V.S., Transpiration, leaf temperature and water potential of rice and barnyard grass in flooded fields, Agric. Meteorol. 26 (1982) 285-296.

[25] OToole J.C., Hsiao T.C., Namuco O.S., Panicle water relations during water stress, Plant Sci. Lett. 33 (1984) 137-143.

[26] Peng S., Laza R.C., Khush G.S., Sanico A.L., Visperas R.M., Garcia F.V., Transpiration efficiencies 
of indica and improved tropical japonica rice grown under irrigated conditions, Euphytica (1998) (accepted).

[27] Rackham O., Temperatures of plant communities as measured by pyrometric and other methods, in: Evans G.C., Bainbridge R., Rackham O. (Eds.), Light as an Ecological Factor II, Blackwell, Oxford, 1975, pp. 423-449.

[28] Satake T., Yoshida S., High temperature induced sterility in indica rice at flowering, Jpn J. Crop Sci. 47 (1978) 6-17.

[29] Scholes R.J., Walker BH, An African Savanna: Synthesis of the Nylsvley Study, Cambridge University Press, Cambridge, 1993.

[30] Smith W.K., Knapp A.K., Reiners, W.A., Penumbral effects on sunlight penetration in plant communities, Ecology 70 (1989) 1603-1609.

[31] Stoutjesdijk P., Barkman J.J., Microclimate, Vegetation and Fauna, Opulus, Knivsta, Sweden, 1992.

[32] Surano K.A., Daley P.F., Houpis J.L.J., Shinn J.H., Helms J.A., Palassou R.J., Costella M.P., Growth and physiological responses of Pinus ponderosa (Dougl. ex P. Laws.) to long-term elevated $\mathrm{CO}_{2}$ concentrations, Tree Physiol. 2 (1986) 243-259.
[33] Swinbank W.C., Long-wave radiation from clear skies, Q. J. R. Meteorol. Soc. 89 (1963) 339-348.

[34] Trewartha G.T., Horn L.H., An Introduction to Climate, McGraw-Hill, London, 1980.

[35] Woodward F.I., Sheehy J.E., Principles and Measurements in Environmental Biology, Butterworth, London, 1983.

[36] Ying J., Peng S., He Q., Yang H., Yang C., Visperas R.M., Cassman K.G., Comparison of highyield rice in a tropical and subtropical environment. I. Determinants of grain and dry matter yields, Field Crops Res. (1998) (in press).

[37] Yoshida S., Parao F.T., Performance of improved rice varieties in the tropics with special reference to tillering capacity, Exp. Agric. 8 (1972) 203-212.

[38] Ziska L., Manalo P., Ordonez R., Intraspecific variation in the response of rice (Oryza sativa $\mathrm{L}$.) to increased $\mathrm{CO}_{2}$ : Growth and yield of response of $17 \mathrm{cul}-$ tivars, J. Exp. Bot. 47 (1996) 1353-1359.

[39] Ziska L., Namuco O., Moya T., Matsui T., Quilang J., Growth and yield response of field-grown rice to increasing $\mathrm{CO}_{2}$ and temperature, Agron. J. 89 (1997) 45-53.

\section{APPENDIX A: Definition of symbols}

\begin{tabular}{|c|c|c|}
\hline Symbol & Definition and equation where first mentioned & Units \\
\hline A & Area of an object; (1) & $\mathrm{m}^{2}$ \\
\hline $\mathrm{E}$ & Rate of transpiration; (10) & $\mathrm{kg} \mathrm{m}^{-2} \mathrm{~s}^{-1}$ \\
\hline $\mathrm{F}_{W}$ & Rate of water loss; (1) & $\mathrm{kg} \mathrm{s}^{-1}$ \\
\hline$F_{H}^{w}$ & Sensible heat loss; (1) & $\mathrm{W} \mathrm{m} \mathrm{m}^{-2}$ \\
\hline$I_{n}^{n}$ & Incident PAR on a spikelet; (2) & $\mathrm{W} \mathrm{m}^{-2}$ \\
\hline $\mathrm{I}_{\mathrm{pb}}^{\mathrm{p}}$ & Incident PAR on a spikelet, direct beam only; (16) & $W \mathrm{~m}^{-2}$ \\
\hline $\mathrm{R}_{\mathrm{lw}}^{\mathrm{b}}, \mathrm{R}_{\mathrm{lw}}^{\prime}$ & $\begin{array}{l}\text { Net longwave radiation exchanged by spikelet with its } \\
\text { surroundings, on top or bottom surface; }(2-4)\end{array}$ & $\mathrm{W} \mathrm{m}^{-2}$ \\
\hline $\mathrm{R}_{\text {nellw }}$ & Net longwave radiation emitted or absorbed; (1) & $\mathrm{W} \mathrm{m}^{-2}$ \\
\hline $\mathrm{R}_{\mathrm{g}}^{\text {nellw }}$ & Global (shortwave) radiation received; (1) & $W \mathrm{~m}^{-2}$ \\
\hline $\mathrm{T}_{K A}^{\mathrm{g}}$ & Absolute air temperature & K \\
\hline $\mathrm{T}_{\mathrm{KS}}^{\mathrm{KA}}$ & Absolute temperature of non-transpiring spikelet & $\mathrm{K}$ \\
\hline $\mathrm{T}^{\mathrm{KS}}$ & Temperature of an object; (1) & ${ }^{\circ} \mathrm{C}$ \\
\hline $\mathrm{T}_{\mathrm{A}}$ & Air temperature; (2) & ${ }^{\circ} \mathrm{C}$ \\
\hline $\mathrm{T}_{\mathrm{B}}^{\mathrm{A}}$ & Temperature corresponding to the thermal burden; (6) & ${ }^{\circ} \mathrm{C}$ \\
\hline 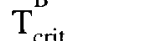 & Any specified spikelet temperature; (11) & ${ }^{\circ} \mathrm{C}$ \\
\hline$T_{i}$ & Temperature of incoming water; (1) & ${ }^{\circ} \mathrm{C}$ \\
\hline$T_{s}$ & Temperature of non-transpiring spikelet; (5) & ${ }^{\circ} \mathrm{C}$ \\
\hline$T^{s}$ & Temperature of transpiring spikelet; (9) & ${ }^{\circ} \mathrm{C}$ \\
\hline $\mathrm{T}_{\text {terr }}^{3}$ & Temperature of any terrestrial surface; (8) & ${ }^{\circ} \mathrm{C}$ \\
\hline$c_{p}^{\text {terr }}$ & Specific heat capacity of air at constant pressure; (1) & 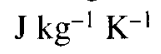 \\
\hline
\end{tabular}

